\title{
CENTRAL BANKS: HESITANT GUARDIANS OF EQUILIBRIUM
}

\author{
Jerzy HAUSNER - Andrzej SŁAWIŃSKI
}

In our paper we focus on situations when central banks have to conduct monetary policy in a world in which they cannot rely fully on what is regarded the best practice and they have to cope with financial system inherent tendency to be unstable. Both phenomena are rooted in János Kornai's intellectual heritage highlighting that economy tends to divert from equilibrium and that soft budget constraint erodes economic actors' behavior.

Keywords: monetary policy, financial stability, equilibrium

JEL classification indices: E44, E52, E66

Jerzy Hausner, corresponding author. Professor at Cracow University of Economics. E-mail: hausner@uek.krakow.pl

Andrzej Stawiński, Professor at Warsaw School of Economics. E-mail: aslawi@sgh.waw.pl 
For Kornai, like for Mises, the world of equilibrium, or what Mises called the "evenly rotating economy" is an indispensable mental tool for understanding economic theory. But it is demonstrably not about the world we live in and cannot tell us about the actual economic problems - "the big questions" to use Kornai's language - we actually face.

(Peter Leeson 2007)

\section{INTRODUCTION}

Central banks have to be credible. They have to win public trust that they are able to keep the economy on an equilibrium growth path. However, they are aware that the world is not ergodic (self-replicating), which makes the future uncertain, and they have to base their decisions on unobservable values such as the natural rate of unemployment and the potential rate of growth. Moreover, what is regarded as the best practice for central banks may become outdated due to the structural changes in the economy. All this makes central banks hesitant guardians of the economy's equilibrium.

Being former interest rate setters, ${ }^{1}$ we experienced such situations. We remember how frequently we were asked whether our central bank was behind the curve. This question was usually a polite suggestion that we might perhaps already be late with hiking interest rates soon enough to prevent a developing wage-cost spiral. A prudent Monetary Policy Committee member was expected to be ready to vote for preemptive interest rate hikes to hedge the economy against the risk of second-round effects. However, in practice, the choice may be much more complex.

A good example is Poland in 2007-2008, when the rates of GDP and wage growth were relatively high and the mortgage market was booming. Under normal circumstances, a decision to raise interest rate would be obvious. In 2007-2008, it raised doubts. The problem was that a large part of bank mortgage lending was in Swiss francs at that time. This produced the risk that hiking interest rate might make foreign exchange loans even more attractive due to the widening of interest rate differential and further Polish zloty appreciations (driven by carry trade).

The important factor making the National Bank of Poland's (NBP) choice difficult was that property prices on the US mortgage market collapsed already in autumn 2006. Since 2007, the IMF and the BIS were suggesting that this might trigger a recession in the American economy, as was invariably the case during

1 In the 2000s, we had the honor of being members of the Monetary Policy Council of the National Bank of Poland. 
the whole period after World War 2 with the exception of the ending of the Korean War and the burst of the Dotcom Bubble.

All in all, the NBP decided for a moderate increase in interest rate, which was a compromise between taking into consideration the ensuing slowdown in the global economy and adhering to the best practice demanding central banks to shield the economy from second-round effects.

Following this introductory example, we turn to our discussion of the factors that make central bankers hesitant guardians of equilibrium. Section 2 reflects on some well-described instances of monetary boards decisions, which, although considered fully rational at the time of their making, proved to be counterproductive in the ex-post assessment. Our conclusion is that those decisions were commonly driven by the policy-makers' adherence to the prevailing best practice of monetary policy, which (being based on history) proved to be misleading in the light of structural changes in the economy. Section 3 focuses on the still controversial decisions of central banks to engage in quantitative easing following the Lehman collapse. While decisions can be considered to go against the previously prevailing best practice, we argue that it was justified in the light of the threat to financial stability, which has become a new territory of central banking. Section 4 concludes. We finish our paper with a tribute to János Kornai's intellectual heritage.

\section{BELIEFS AND DECISIONS}

The period of the gold standard system before 1914 was favorable for central banks. In general, they did not face difficult choices. Luckily, the rate of growth in gold and money supply tended to be consistent with the rate of GDP growth, which tended to secure price stability (Cassel 1936). The lack of the exchange rate risk facilitated the constant recycling of capital from creditor to debtor countries, which contributed to international equilibrium. Due to the high price elasticity of capital flows, central banks' interest rate policy had a kind of fine tuning role. The purpose was to induce capital inflows when it was necessary to stabilize the stock of gold reserves. Central banks did not sterilize flows of gold, which created a historically unique situation when adjustments in creditor and debtor countries economies were symmetric.

The interwar gold standard was different. Central banks were taking unfortunate decisions under the pressure of the dominant beliefs on what was the best practice.

In the 1920s, the Bank of France was motivated by the belief that the part of foreign exchange reserves that was not in the form of gold may constitute infla- 
tionary pressure. This belief pushed the Bank into the unfortunate decision of converting its foreign exchange reserves into gold, which deepened the relative shortage of gold reserves in deficit economies (Irwin 2011).

The relative shortage of gold in the deficit countries was alleviated by capital outflows from the United States and the United Kingdom. Nonetheless, the Federal Reserve sterilized the growth in its gold reserves, which forced deficit countries to keep their interest rates on a relatively high level in order to attract capital inflows.

The unfortunate decision of the Bank of England to return to the prewar gold parity despite the fact that since the outbreak of World War 2, inflation in the United Kingdom was significantly higher than in the United States. The resulting overvaluation of the British pound hampered British exports. Maintaining its price competitiveness was costly in terms of economic growth because the structural changes in the British economy produced price and wage stickiness.

In the early 1930s, the factor that contributed to the transformation of the initial recession into the Great Depression was the Federal Reserve's unfortunate decision not to provide sufficient liquidity to banks during the early days of the bank run. This led to massive bank bankruptcies and a fall in money supply by a third (Simons 1936).

The Federal Reserve's decision was probably motivated by an adherence to the then dominant liquidationist view of the Austrian School, which maintained that recessions were necessary for enabling economies to get rid of excessive investments (De Long 1990). While it is difficult to assess to what extent the Federal Reserve was actually motivated by the Austrian School beliefs (White 2008), both Friedrich Hayek and Lionel Robbins admitted that in the 1930s they underestimated the impact of deflation on deepening the crisis (Hayek1975; Robbins 1979).

In the 1930s, it turned out that fiscal expansion might be necessary to revitalize investment and effective demand during protracted economic stagnation and depressed expectations. In the 1950s and the 1960s, it was believed that a mixture of expansionary fiscal and monetary policy is essential to keep the economy on an equilibrium growth path. Central banks became government-dependent and their task was to contribute to stabilizing effective demand and employment.

In the late 1950s, the emergence of the Phillips curve allowed central banks to believe that they might choose the right combination of inflation and the rate of unemployment. In the late 1960s, Friedman and Phelps warned that using monetary expansion for enhancing economic growth might boost inflationary expectations and develop a second-round effect, i.e., a wage-price spiral (Gordon 2008). 
During the two oil shocks of the 1970s, this risk materialized. Phillips curve indeed heavily steepened. In several countries inflation increased sharply without simultaneous decrease in unemployment rate. The stagflation ensued. The structural factors which facilitated wage-price spiral to develop was the growing bargaining power of trade unions after long post-war recovery and the relative weakness of the global price competition.

Central banks were hesitant to raise interest rates sharply, as they were afraid that it might be costly due to the wage and price stickiness. Only the Bundesbank and the Swiss National Bank hiked interest rates sufficiently to shield their economies from price-wage spiral. They could do this as in contrast to other central banks they were already at that time independent from the government.

In the 1980s, central banks were gaining independence one by one and they implemented a tight monetary policy despite that disinflation turned out to be costly in terms of growth and unemployment (Goodhart 2017). Nonetheless, central banks succeeded in stabilizing inflation and inflationary expectations at a low level, which brought about a permanent decrease in long-term interest rates. In the 1990 s, central banks adopted an inflation targeting policy as it was better suited to low inflation than the previous strategy of controlling monetary aggregates.

The disinflation of the 1980s was facilitated by structural changes. Most important among these were the weakening of the trade unions due to legal changes and the shrinking share of traditional industries. The fading trade unions' bargaining power and technological change started to produce an increasing productivity-wage gap. At the same time, globalization made international price competition much stronger, which narrowed the scope for wage increases. The Phillips curve was flattening in the 1980s. The development of a strong wage-price spiral seemed increasingly less possible.

Nonetheless, the best practice for central bankers still was to prevent the development of second-round effects. The dominant New Keynesian belief was that stable inflation is the necessary and sufficient condition for keeping the economy on the equilibrium growth path (Alesina et al. 2001). One example was the ECB's decision to hike interest rate in 2008 when economic growth was slowing down.

The reasons behind this decision were worries that the rise in inflation, caused by rising oil and other commodity prices, may induce second-round effects. The hike was pre-announced in the ECB's monthly bulletin emphasizing the risk of a price-wage spiral. The decision was taken despite some other euro zone central banks were not seeing the necessity to raise interest rates. In May 2008, the Banca d'Italia monthly bulletin underlined that the 2000s were not similar to the 1970 s due to the much weaker trade unions bargaining power and much stronger international price competition. 
Of course, when assessing ex post the ECB decisions, one has to consider that no-one was able to predict that the collapse of Lehman Brothers in autumn 2008 would drastically deepen the global banking crisis and lead to worldwide recession. Before the Lehman collapse, it seemed that central banks succeeded in coping with the acute global liquidity crisis. Forecasts at that time indicated a mild and relatively short recession. Nonetheless, the ECB's decision was an example of an excessive adherence to what was believed to be the best practice at a given time.

After the outbreak of the global banking crisis, the balance sheet recessions forced a number of central banks to implement unconventional instruments. The most important was quantitative easing (QE). From a technical point of view, the QE programs constituted massive central bank interventions mainly on the treasury bond market to engineer a fall in long-term interest rates. The still unappreciated benefit of $\mathrm{QE}$ is an effective reduction of public debts, as the QE programs effectively convert Treasury bonds, which are in central banks' assets, into zero-coupon consoles (Paris - Wyplosz 2014). This results from the fact that the central banks give back to the government both interest payments in the form of seigniorage and principal payments through reinvesting them on the secondary Treasury bond market. Hence, the QE programs contributed to economic recoveries by creating more fiscal space for governments.

The recent situation illustrates why central banks cannot escape from being hesitant guardians of equilibrium: on the one hand, they intend to tighten monetary policy in order to tame excessive risk-taking in the financial sector, while on the other hand, they still cannot count on fully convincing explanation of the riddle of why the rate of growth in wages is unexpectedly low despite historically low rates of unemployment (Haldane 2017).

As far as more distant horizons are concerned, a potential materialization of secular stagnation risk might limit the scope for conducting a conventional monetary policy. Central banks would have to re-invent their role and the terms of coordination with fiscal authorities. The Japanese example illustrates that this may take a long period of time.

\section{FINANCIAL STABILITY CHALLENGES}

Financial institutions' tendency to take excessive risks results mainly from the two factors. On the one hand, they enjoy soft budget constraint as they are able to create themselves the sources of their funding, e.g. wholesale (mainly interbank) deposits. On the other hand, the informational efficiency of financial markets creates situation in which the only way to increase the rate of return (apart from 
increasing incomes from fees) is to take more risks. Under such circumstances financial institution display a tendency to use leverage in order to increase risk and the expected rate of return. Additionally, the emergence of the vast global short-term wholesale money markets (used for funding short-term arbitrage and winding up leverage) banks became highly interconnected (Goodhart - Perotti 2015). It became necessary to save large and highly interconnected banks in order to shield the economy from the systemic risk. Knowing this the too-big-tofail banks (TBTF) were taking excessive risks. They assumed that in emergency they would be bailed out with taxpayer money. And they were regrettably right. During the recent global banking crisis only Lehman Brothers was allowed to bankrupt.

\subsection{The procyclicality of shadow money creation}

The recent crisis was caused by a number of factors. The two most important causes were the large scale of using short-term interbank deposits for funding long-term mortgage loans and the massive issuance of illiquid (i.e., risky) structured bonds, of which the most spectacular example were the Collateralized Debt Obligations (CDOs). The large investment banks yielded to the temptation of purchasing these illiquid bonds, while their natural habitat was to be involved in short-term arbitrage transactions (mainly relative value trades) on liquid markets. Due to the sharp fall across asset-backed securities prices (including CDOs) universal and investment banks took large losses, which triggered liquidity crisis augmented by the runs on repo markets (Copeland - Walker 2012).

Bearing in mind the experiences of the 1930s, central banks provided banks and non-bank financial institutions with ample liquidity. The Federal Reserve began to play the role of the global lender of last resort providing liquidity to European central banks and directly to European large banks. One of the reasons was that before the crisis, European banks were massively taking deposits from US money market funds to buy Asset-Backed Commercial Papers (ABCP) issued by the US securitization funds. After the outbreak of the crisis, they lost access to the dollar financing of their liabilities. The gap was filled by the Federal Reserve (Broz 2015).

Before the crisis, it was believed that the progress in measuring and managing risk would create a situation in which banks will effectively adjust their potential losses to their capital, which was believed to hedge banks from the bankruptcy risk. The assumption was that solvent banks would always have access to liquidity. This is why Basel II did not regulate liquidity management in banks. 
After the crisis, Basel III imposed the new rules of managing liquidity, which addressed the problem of banks funding long-term mortgage loans with shortterm wholesale deposits. Nevertheless, the creation of short-term funding for the shadow banking system remains unregulated.

In his recent book, Richard Bookstaber depicts financial system as a threelevel construction whose ultimate purpose is trading done by dealing rooms of many different financial institutions (Bookstaber 2017). The dealing rooms are connected with the units that deliver short-term funding and borrow securities enabling collateralized borrowing on the repo market or through rehypothecation. The backbone of the whole structure is represented by broker-dealer banks, which trade with many different kinds of shadow banks such as hedge funds, securitization funds, etc. The problem is that it is difficult to predict how such a system will evolve (Tarullo 2017b). One of the risk factors is that a part of corporate chronically excess savings flow (through the repo market) to fund shadow banks holding highly leveraged portfolios of illiquid bonds, which caused a cumulation of risk within the financial system (Pozsar 2014).

\subsection{Free banking, digital currencies, and narrow money}

Nowadays we witness the emergence of privately issued digital monies. This recalls the period of free banking, when commercial banks were issuing hundreds of different banknotes. These banknotes played the role of money because they were convertible into gold (species) at a fixed rate. If digital monies were to be actual money, they would have to be convertible into some kind of legal tender (cash, central bank reserves) at a fixed rate. Without this, they will continue to remain assets, as is the case today, which constitutes an additional financial stability risk factor.

It is worth recalling why there had been no overissuance of money during the free banking era. The reason was that at that time, banks were extending mainly short-term self-liquidating working capital loans. In such a situation, credit and money creation tended to adjust to the demand for money. The problem with digital monies is that they do not enter the economy through the creation of shortterm self-liquidating loans. There is no mechanism potentially adjusting their supply to the demand for money.

In 1948, Friedman proposed such a mechanism, assuming that the volume of tax revenues and expenditures might be set in such a way that the budget would be in balance when the economy grew at a rate consistent with its potential. Consequently, a budget deficit would signal that the economy is growing below its 
potential. Under such assumptions, money financing of the budget deficit would mean nothing more than adjusting the money supply to demand, consistent with the equilibrium growth path. Similarly, a budget surplus would signify that the GDP growth is above the economy's potential. Thus, through investing budget surpluses in capital markets, the government would destroy a part of money supply, adjusting it to a money demand consistent with potential GDP growth (Friedman 1948).

Milton Friedman's proposal is exceptional in its clarity, even if it would not be politically viable to construct a budget fulfilling conditions he formulated. In general, however, the alternative banking reform schemes do not offer specific macroeconomic recipes as to how the state could create and control money supply. A likely reason for this omission is the difficulty to devise a system that would be fully resistant to the government misuse of its power to issue money.

Even if central banks decided to issue their own digital money, e.g., to eliminate cash and circumvent the zero lower bound in their interest rate policy, they would encounter the same problem that emerged when narrow money concept (government issued money) was put forward (Simons 1936). The proposal envisaged that households and corporations would hold their money balances with narrow banks, which would keep their assets in the form of the central bank's liquid reserves and short-term government paper.

The intention of the narrow banking proposal was to solve the bank runs problem plaguing the US banking system in the $19^{\text {th }}$ century. Despite the fact that the deposit insurance system eliminated this problem (in the case of retail deposits), the proposal of narrow banking reappeared (Benes - Kumhof 2012), which was a reaction to the stalemate in credit and money creation after the recent banking crisis.

Nonetheless, the implementation of the narrow banking concept would pose risks to financial stability. The problem is that if narrow banks were holding their assets in the form of liquid reserves held with central bank and in the form of short-term Treasury bills, some other financial institutions (e.g. savings banks) could have to extend loans. Due to the risk premium, they would earn more than the narrow banks and would offer higher interest on deposits. Under these circumstances, households and firms would move their deposits from narrow banks to lending institutions in times of economic expansion, while there would be outflows of deposits from lending institutions to narrow banks during economic downturns. This might make the banking system highly procyclical (Goodhart 1994). 


\subsection{The problem of mortgage lending}

Whatever the weaknesses of the narrow money proposal, the problem which caused its reappearance was the change of the banking business model which made banks exposed to severe mortgage crises having the potential to put credit and money creation to a halt (during balance sheet recessions) as was the case in Japan after the 1990 crisis and in several countries after the 2007 crisis.

The change in the banking model took place in the 1970s and the 1980s. Previously, banks were relatively safe institutions extending mainly working capital loans to the corporate sector. This changed when universal banks started to build large trading portfolios and then entered mortgage lending en masse.

Both changes generated a greatly increased demand for wholesale short-term funding which was created on the interbank money market. Due to the banks' adoption of the new business model, the average bank rates of return became much higher, although at the cost of their much higher volatility. The massive use of wholesale short-term funding made banks much more interconnected, which exposed them to the increased systemic risk (Shin 2012; Jorda et. al. 2015).

One of the solutions proposed after the 2008 global banking crises was ringfencing, i.e., limiting commercial banks' activities to their core business. The problem is that mortgage is does also assumed to be commercial banks' core activity despite its high procyclicality (Leamer 2007). Moreover, contrary to common belief, mortgage lending does not (and should not) create money. Money supply consisting of households and firms' bank account balances that are held to fund their current spending on goods and services. The buyer of a house typically does not use a mortgage loan to cover his or her current spending. ${ }^{2}$ Similarly, the seller of a house usually does not use the revenues to cover his or her ongoing expenditures on goods and services.

To neutralize the risk that mortgage crashes followed by severe banking crises might again put credit and money creation to a halt, strong institutional precautions should be adopted to limit mortgage loan funding to the loanable savings. This would need to give central banks convincing mandate to use monetary and macroprudential policies for containing housing booms.

2 The exceptions were mortgage equity withdrawals (MEW) enabled refinancing of mortgage loans when property prices were risking before the recent global financial crisis (GreenspanKennedy 2008). 


\section{CONCLUDING REMARKS}

During the gold standard system, central banks were focused on keeping external equilibrium, which was perceived to be sufficient due to the strong self-regulatory capacities of market economies. The experiences of the Great Depression refocused central banks on their role in keeping internal equilibrium in their domestic economies.

After World War 2, central banks were expected to stabilize overall demand. Since the late 1950s, the Phillips curve seemed to offer the possibility to choose the best possible combination of rate of unemployment and inflation. The experiences of the 1970s illustrated that using monetary expansion to boost economic growth may steepen the Phillips curve and produce stagflation. The steep shape of the Phillips curve triggered the decision to give central banks independence and concentrate their role on stabilizing inflation.

The New Keynesian models, providing the intellectual foundation for modern monetary policy, assumed that central banks may concentrate on stabilizing inflation as credit and money creation is neutral for the economy in the long run. Hyman Minsky's (1982) financial instability hypothesis was ignored until the outbreak of the recent global banking crisis (McCulley 2009).

The experiences of the recent global banking crisis and the Great Recession it caused (along with Japan's lost decades) revealed that monetary policy might not be effective enough in overcoming a protracted weakness of the domestic demand, which in the case of secular stagnation may call for a reinterpretation of the way monetary and fiscal policies are coordinated.

The two important factors leading to the 2007-2008 global banking crisis were the unsustainable mortgage booms and the massive issuance of illiquid (i.e., risky) asset-backed securities (ABS). Both were financed with short-term wholesale funding. After the crisis, Basel III limited the possibilities of using short-term funds for mortgage loan funding. Nonetheless, the shadow money, e.g., deposits created on the repo market, still finance shadow banks' assets stuffed with illiquid bonds. Central banks, as independent institutions, are best suited to conduct effective macroprudential policy aimed at curbing financial cycles. However, the arsenal of their macroprudential policy does not seem sufficient to meet the task (Borio 2015).

We would like to conclude by underlining that being hesitant is actually a major advantage of monetary policy decision-makers. The ability to verify the adequacy of the prevailing best practice to the constantly evolving economy proves to be critical to steering through the rough waters of the uncertain future. $D u$ bito ergo cogito is more than relevant for monetary policy (Yellen 2017; Tarullo 2017a; Wyplosz 2017). 


\section{GENERAL DISCUSSION}

In our paper we show that central banks cannot rely fully on what is considered the best practice in conducting monetary policy and they have to cope with financial system inherent instability resulting from the fact that financial institutions (especially banks) enjoy soft budget constraint being able to create themselves their sources of funding, e.g. the wholesale deposit market. Both notions, i.e. the non-ergodicity of the economic systems and the soft budget constraint, are deeply rooted in János Kornai intellectual heritage.

János Kornai's Anti-Equilibrium. On Economic Theory and Tasks of Research, originally published in 1971 (Amsterdam: North-Holland Publishing Company) was a pioneering work not only because it delivered insightful criticism of the theory of general equilibrium. It played an important role in this respect since the subsequent elaborations and developments of the theory - influenced by his criticism - were based on increasingly more realistic assumptions. Its pioneering importance is that Kornai questioned the view that economic systems tend to operate in an equilibrium.

János Kornai's work blazed the trail followed today by many economists. But his publications apply to many fields of social sciences. The perhaps most inspiring example is his book Non-Equilibrium Social Science and Policy. Introduction and Essays on New and Changing Paradigms in Socio-Economic Thinking (eds Johnson et al. 2017).

Adopting the cognitive perspective proposed by Kornai, we reject the belief that economic systems tend to return to a sustainable equilibrium. Instead, they are often characterized by disequilibrium. Hence, the fundamental research question is whether or not such disequilibrium leads to the collapse or gradual decomposition of the entire system. It is therefore important to consider what is essential for keeping economic systems in a state of a stable disequilibrium and how to prevent the occurrence of unstable disequilibria leading to serious crises or long-term stagnation

The instability of social systems (not only of economic ones) can be perceived as a tension between their functionality and dysfunctionality. We believe that all social systems may gradually become dysfunctional in the course of their development. They undergo similar processes as the human body, which ages and transforms. It means that in time, all social systems start to exhibit different degrees of disability, which are signs of their routinization and rigidity as well as of the formation of an array of interests within them, which petrifies them, limits their flexibility, and adversely affects system adaptability. It always happens in a specific historical context in consequence of the actions of certain social actors 
and the relations between them. But in principle, whatever happens, the whole system evolves in a similar way.

It should be noted that just as in the case with human bodies, certain "self-corrective" mechanisms are built into social systems. They operate automatically. They do not restore equilibrium, but prevent increasing imbalance from threatening the stability of a given system. And systems that have such built-in compensation mechanisms have a higher adaptive capacity and are thus more efficient in the long run.

However, if a given system is seriously dysfunctional, these automatic mechanisms may not be sufficient and the system loses its stability.

Since social systems are gradually becoming dysfunctional, they need to have their functionality restored through reforms from time to time. If they are not reformed, the process of their dysfunctionalization gradually leads to their collapse. The complexity of the problem is that the system's internal forces are often insufficient for implementing a system-wide reform. In these cases, reform can only be achieved by incorporating external energy, which derives from a broader institutional order.

No economic system is perfect or devoid of weaknesses. No system is free of serious problems or capable of solving all of them. At the same time, not one of them is immutable - each constantly transforms itself and evolves. In no economic system is it possible to achieve a sustainable equilibrium. Constant change is a feature of modern societies; consequently, no equilibrium can be permanent. Each state of balance is temporary and fragile.

Certainly, it is possible to try and preserve a system's balance by means of far-reaching state interference in the market and in the economy as a whole. However, this invariably leads to the centralization of economic power and the nationalization of the economy. A balance thus achieved hinders innovation and development, and, in consequence, undermines democracy. Such a route has always led to the backwoods of history.

We can also assume that we are doomed to disequilibrium; however, we can opt for its aspects that together contribute to development and reasonably limit the consequences of those traits that are socially painful. This is an area where institutional solutions, clearly favored by János Kornai, are to be sought.

Currently, we can observe a spectacular example of the necessity of institutional change. The recent global financial crisis and the Great Recession it caused could not be alleviated without large-scale state intervention. Without it (e.g., large-scale QE programs), the recession would have been much deeper and more protracted. Without significant institutional reform (e.g., establishing macroprudential authorities in a number of countries and implementing a number of new tools for stabilizing financial system), we might have been witnessing a much longer period of economic and financial disarray. 


\section{REFERENCES}

Alesina, A. - Blanchard, O. - Gali, J. - Giavazzi, F. - Uhlig, H. (2001): Defining a Macroeconomic Framework for the Euro Area. Monitoring the European Central Bank, No. 3, CEPR Press, London.

Benes, J. - Kumhof, M. (2012): The Chicago Plan Revisited. IMF Working Paper, No. 202.

Bookstaber, R. (2017): The End of Theory. Financial Crises, the Failure of Economics, and the Sweep of Human Interaction. Princeton University Press.

Borio, B. (2015): Macroprudential Frameworks: (Too) Great Expectations? In: Schoenmaker, D. (ed.): Macroprudentialism. A VoxEU.org Book, CEPR Press, London, pp. 29-46.

Broz, J. L. (2015): The Federal Reserve as Global Lender of Last Resort 2007-2010. Systemic Risk Centre Discussion Paper, No. 30. LSE.

Bullard, J. (2017): Does Low Unemployment Signal a Meaningful Rise in Inflation. The Regional Economist, III Q. Federal Reserve Bank of St. Luis.

Cassel, G. (1936): The Downfall of the Gold Standard. Oxford: Calderon Press.

Copeland, A. - Walker, M. A. (2012): Repo Runs: Evidence from Tri-Party Repo Market. Staff Report, No. 506. Federal Reserve Banks of New York.

De Long, B. J. (1990): Liquidation Cycles: Old-Fashioned Real Business Cycles Theory and the Great Depression. NBER Working Paper, No. 3546.

Friedman, M. (1948): A Monetary and Fiscal Framework for Economic Stability. American Economic Review, 38(June): 245-264.

Goodhart, C. A. E. (1994): The Free Banking Challenge to Central Banks. Critical Review, 8(3): 411-425.

Goodhart, C. A. E. (2017): Populism and Central Bank Independence. CEPR Discussion Paper, No. 12122.

Goodhart, C. A. E. - Perotti E. (2015): Maturity Mismatch Stretching: Banking has Taken a Wrong Turn. Financial Markets Group Special Paper, No. 235, LSE.

Gordon, J. R. (2008): The History of the Phillips Curve. Australasian Meeting of the Econometric Society, 9-11 July, Wellington, New Zealand.

Greenspan, A. - Kennedy, J. (2007): Sources and Uses of Equity. Extracted from Houses, Finances and Economic Discussion Series, No. 2007-20, Federal Reserve Board, Washington, D.C.

Haldane, A. G. (2017): Work, Wages and Monetary Policy. Bank of England.

Hayek, F. A. (1975): A Discussions with Friedrich A. von Hayek. American Enterprise Institute, Washington, D. C.

Irwin, D. A. (2011): Anticipating the Great Depression? Gustav Cassel's Analysis of the Interwar Gold Standard. NBER Working Paper, No. 17597.

Johnson, J. - Nowak, A. - Ormerod, P. - Rosewell, B. - Zhang, Y.-C. (eds) (2017): Non-Equilibrium Social Science and Policy. Introduction and Essays on New and Changing Paradigms in Socio-Economic Thinking. Springer e-book.

Jorda, O. - Schularick, M. - Taylor, M. A. (2014): The Great Mortgaging: Housing Finance, Crises, and Business Cycles. Working Paper, No. 2014-23, Federal Reserve Bank of San Francisco.

Kornai, J. (2014): An Introductory Study to Volume IV of the Life's Work Series. Acta Oeconomica, 64(S1): 25-79.

Kornai, J. (2016): The System Paradigm Revisited. Clarification and Additions in the Light of Experiences in the Post-Socialist Region. Acta Oeconomica, 66(4): 547-596.

Leamer, E. E. (2007): Housing IS the Business Cycle. NBER Working Paper, No. 13428.

Leeson, P. T. (2007): By Force of Thought. We're All Austrians Now: Janos Kornai and the Austria School of Economics. In: Warren, S. - Biddle, J. E. - Emmett, R. B. (ed.): Research in the His- 
tory of Economic Thought and Methodology. Emerald Group Publishing Limited, Vol. 26, pp. 209-2019.

McCulley, P. (2009): The Shadow Banking System and Hyman Minsky's Economic Journey. The Research Foundation of CFA Institute.

Minsky, H. P. (1982): Can "It" Happen Again? A Reprise. Challenge, July-August: 5-13.

Paris, P. - Wyplosz, Ch. (2014): The PADRE Plan: Politically Acceptable Debt Restructuring in the Eurozone. Geneva Reports on the World Economy, Special Report 3, CEPR Press.

Pozsar, Z. (2014): Shadow Banking: Money View. Office of Financial Research Working Paper, No. 14-04.

Robbins, L. (1979): Against Inflation: Speeches in the Second Chamber, 1965-1977. London: Macmillan.

Shin, H. S. (2012): Global Banking Glut and Loan Risk Premium. Paper presented at $12^{\text {th }}$ Jacques Polak Annual Research Conference, IMF, Washington, D. C.

Simons, H. C. (1936): Rules vs. Authorities in Monetary Policy. Journal of Political Economy, XLIV(February): $1-30$.

Sławiński, A. (2016): The Role of the ECB's QE in Alleviating the Eurozone Debt Crisis. Prace Naukowe Uniwersytetu Ekonomicznego we Wrocławiu, No. 428.

Tarullo, D. K. (2017a): Monetary Policy without a Working Theory of Inflation. Hutchins Center Working Paper, No. 33.

Tarullo, D. K. (2017b): Thinking Critically about Nonbank Financial Intermediation. Brookings Institution, Washington D.C.

Yellen, J. L. (2017): Inflation, Uncertainty, and Monetary Policy. National Association for Business Economics, Cleveland, Ohio.

White, L. H. (2008): Did Hayek and Robbins Deepen the Great Depression? Journal of Money, Credit and Banking, 40(4): 751-768.

Wyplosz, Ch. (2017): How Far should Unconventional Central Banking Go? CESifo DICE Report, vol. 15. 